UDC $546.98+546.922+547-305+577.112 .7$

\author{
P.V. Borovyk ${ }^{a}$, S.I. Orysyk ${ }^{a}$, H.H. Repich ${ }^{a}$, A.F. Likhanov ${ }^{b}$, A.M. Mishchenko ${ }^{a, e}$, \\ Yu.L. Zborovskii ${ }^{c}$, V.V. Orysyk ${ }^{c}$, L.G. Palchikovska ${ }^{d}$, V.I. Pekhnyo ${ }^{a}$, M.V. Vovk ${ }^{c}$
}

\title{
SPECTRAL CHARACTERISTICS AND CYTOSTATIC EFFECT OF Pd(II) AND Pt(II) CARBOTHIOAMIDE $\pi$-COMPLEXES ON ALLIUM CEPA L MERISTEM CELLS
}

\author{
a V.I. Vernadsky Institute of General and Inorganic Chemistry of the National Academy of Sciences of \\ Ukraine, Kyiv, Ukraine \\ ${ }^{\text {b }}$ Institute for Evolutionary Ecology of the National Academy of Sciences of Ukraine, Kyiv, Ukraine \\ c Institute of Organic Chemistry of the National Academy of Sciences of Ukraine, Kyiv, Ukraine \\ ${ }^{d}$ Institute of Molecular Biology and Genetics of the National Academy of Sciences of Ukraine, \\ Kyiv, Ukraine \\ ${ }^{\text {e }}$ Enamine Ltd., Kyiv, Ukraine
}

\begin{abstract}
The spectral characteristics of the synthesized cisplatin analogs based on $\pi$-complexes of $\mathrm{Pd}(\mathrm{II})$ and $\mathrm{Pt}$ (II) with N-allylmorpholine-4-carbothioamide and 1-allyl-3-tret-butylthiourea and the mechanism of their cytostatic and antiproliferative action on meristem cells of Allium cepa L. are reported in this work for the first time. It is shown that the electronic absorption and diffuse reflection spectra of complexes show absorption bands corresponding to the transitions with charge transfer from a ligand to metal, dd-electron transitions and intraligand $\pi \rightarrow \pi^{*}$ and $\mathrm{n} \rightarrow \pi^{*}$ electronic transitions with the contributions of multiple bonds of allyl moiety and carbothioamide group. In this case, the absorption bands in the ultraviolet region of the spectra of the complexes undergo a hypochromic shift with respect to the spectra of the ligands themselves, which is due to the presence of a coordination link. Analysis of the titration curves shows the possible coordination of the ligands in solution in both chelate and non-chelate ways only through the atoms of sulfur of the carbothioamide group with molar ratios $\mathrm{M}: \mathrm{L}=1: 1,1: 2$ and 1:3. Theoretical quantum-chemical calculations of the IR spectra are carried out; their results are in good agreement with the experimental data of infrared spectroscopy. It is established that cisplatin analogues exhibit a specific cytostatic effect on Allium cepa meristem cells with high antiproliferative activity. Due to the formation of numerous cross-links of metal-containing preparations with DNA molecules and with nuclear proteins, chromatin is not compacting as normal. This results in a disrupted cell cycle, a decreased mitotic index and anomalous cell division, which are usually followed by apoptosis. Palladium-based $\pi$-complexes cause chromatin dispersion, which leads to significant abnormalities in the processes of karyokinesis, which cause the chromosomes to lose their typical structure and undergo fragmentation, mostly with loss of telomeric sites.
\end{abstract}

Keywords: $\pi$-complexes, carbothioamides, vibrational spectroscopy, anticancer activity, genotoxicity.

DOI: $10.32434 / 0321-4095-2020-130-3-34-45$

\section{Introduction}

$\mathrm{N}$-Allyl-substituted thioureas are the original type of ambidentate ligands. The favorable mutual spatial arrangement in their structure of $\mathrm{N}, \mathrm{S}$ nucleophilic atoms and allyl moiety creates for them the prerequisites for the formation of stable six- membered chelate metallocycles with the formation of $\pi$-bonds with ions of a number of metals belonging to «soft» Lewis acids, such as $\mathrm{Pd}(\mathrm{II}), \mathrm{Pt}(\mathrm{II}), \mathrm{Cu}(\mathrm{I})$, $\operatorname{Ag}(\mathrm{I})$, and others [1,2]. Coordination compounds of this type are of interest as catalysts for organic reactions and as potential biologically active

(C) P.V. Borovyk, S.I. Orysyk, H.H. Repich, A.F. Likhanov, A.M. Mishchenko, Yu.L. Zborovskii, V.V. Orysyk, L.G. Palchikovska, V.I. Pekhnyo, M.V. Vovk, 2020

P.V. Borovyk, S.I. Orysyk, H.H. Repich, A.F. Likhanov, A.M. Mishchenko, Yu.L. Zborovskii, V.V. Orysyk, L.G. Palchikovska, V.I. Pekhnyo, M.V. Vovk 


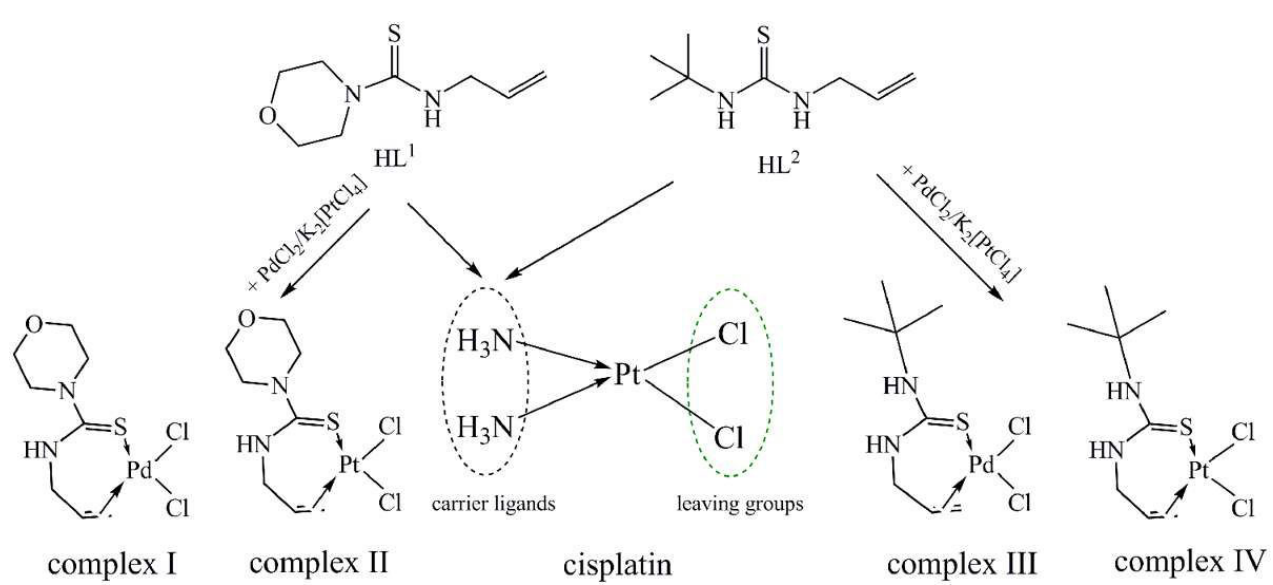

Fig. 1. Schematic molecular structures of ligands $\mathrm{HL}^{1}, \mathrm{HL}^{2}$, complexes I-IV and cisplatin

substances. However, despite the fact that $\pi$-complex compounds of transition metal ions are known for a long time, their biological activity has hardly been studied. In our previous works $[1,3,4]$, we have shown that the synthesized $\pi$-complexes of $\mathrm{Pd}(\mathrm{II})$ and $\mathrm{Pt}(\mathrm{II})$ with $\mathrm{N}$-allylthiourea derivatives (I-IV) exhibit a pronounced antitumor activity which is an order of magnitude higher than known pharmaceutical drug cisplatin (Fig. 1).

In the molecules of cisplatin and its analogues, square-planar coordination polyhedrons are formed on the one hand by «carrying» nitrogen atoms in the cis position and on the other hand by «leaving» group represented by chloride ions. However, unlike cisplatin, in the structure of the complexes synthesized by us, thiourea scaffold are coordinated to $\mathrm{Pd}(\mathrm{II})$ and $\mathrm{Pt}(\mathrm{II})$ ions by even «softer» donor atoms (in conformity with Pearson's classification) with high trans-influence (according to the effect of symbiosis in Pearson's transfusion). Consequently, the affinity of metal ions in the complexes I-IV to the «soft» sulfur atoms of other substances may decrease, which should prevent the binding them with thiol-containing substances which are present in the cytoplasm of cells. As a result, it should hinder the migration of these potential intercalators towards DNA, the main pharmaceutical target. In addition, functionally substituted thioureas are able to influence a number of other biological targets critical for the process of carcinogenesis [5], which is an additional basis for their use in the design of new anticancer agents.

In this work, using spectral methods, we studied the formation of $\mathrm{Pd}(\mathrm{II})$ and $\mathrm{Pt}(\mathrm{II})$ complex compounds with allylthioureas in solutions in order to predict the behavior of these complexes in biological media. The mechanism of their cytostatic and antiproliferative effects on meristem cells of
Allium cepa (as the test object widely used to evaluate the genetic potential of chemical compounds) was also studied. Besides platinum, palladium was also used as a central atom to synthesize novel cisplatin analogues. It should be noted that the structural and thermodynamic similarities with platinum and its lower toxicity make palladium compounds promising objects for the design of new potential antitumor agents, as evidenced by numerous publications $[6,7]$. However, there are only a few reports concerning $\pi$-complexes as objects of search for new anticancer agents [8], which together with taking into account our previous results $[1,3,4]$, makes them promising objects for research in this direction.

\section{Experimental}

Synthesis of complex compounds

Synthesis of complexes I-IV was performed by the method described elsewhere [1]. The IR spectra were recorded using a Specord M80 spectrometer in the frequency range of 4000$400 \mathrm{~cm}^{-1}$ in $\mathrm{KBr}$ pellets. The electronic absorption spectra and diffuse reflectance spectra were measured by a Specord M40 spectrophotometer (in the range of 50000-11000 $\mathrm{cm}^{-1}$ ). Spectrophotometric studies of ligands $\mathrm{HL}^{1}, \mathrm{HL}^{2}$ and complexes I-IV were performed using mixture solvents DMF:ethanol (2:1). The starting solutions for titration were prepared by dissolving the exact weighed sample of $\mathrm{PdCl}_{2}$ or $\mathrm{K}_{2} \mathrm{PtCl}_{4}$ in $4 \mathrm{~mL}$ of $2 \mathrm{M} \mathrm{HCl}$ and the carbothioamides $\mathrm{HL}^{1}$ or $\mathrm{HL}^{2}$ in EtOH. The solution volume was brought to $25 \mathrm{~mL}$ with ethanol. Herewith the concentration of metal salts $\left(\mathrm{C}_{\mathrm{M}}\right)$ was unchanged $\left(10^{-4} \mathrm{M}\right)$, while the concentration of carbothioamides $\mathrm{HL}^{1} / \mathrm{HL}^{2}$ was changed from $1.67 \cdot 10^{-5} \mathrm{M}$ to $33.33 \cdot 10^{-5} \mathrm{M}$.

\section{Computational details}

Geometry optimization with subsequent normal mode analysis of $\mathrm{N}$-allylthioureas $\mathrm{HL}$ and metal 
complexes $\left[\mathrm{M}(\mathrm{HL}) \mathrm{Cl}_{2}\right]$ were performed by means of the density functional theory. A combination of BP86 nonhybrid functional and a polarized triplezeta (TZP) valence basis set in combination with Huzinaga's model core potentials (MCP) was employed. The initial structures were taken from the $\mathrm{X}$-ray diffraction data [1]. The assignment of vibrational modes was achieved based on comparison of experimental and calculated IR spectra. Scale factor of 1.034 was used for the frequencies lower than $1600 \mathrm{~cm}^{-1}$ [9]. Calculations were carried out by using the GAMESS (US) program package. Computing resources were provided by the SCIT supercomputer (V.M. Glushkov Institute of Cybernetics of the NAS of Ukraine).

\section{Allium cepa L. test}

Allium cepa test is a simple, cost-effective and sensitive method for detection of chromosomal mutations. The results obtained using this test correlated highly with the results of studies on mammalian, including human cells [10].

Nuclear DNA was detected with Feulgen stain. Hydrochloric acid hydrolyzes the deoxyribose into an aldehyde which turns red-purple in reaction with fuchsin-sulfurous acid (Schiff's reagent) [11].

Microscopy and photographing of the results of cytological studies were performed by an Axio Scope A1 research class microscope using AxioVision 4.7 software (Carl Zeiss, Germany). Digital bitmap was processed in the specialized program ImagePro Premier 9.0 (Media Cybernetics, USA). The chromatin condensation and DNA content in the interphase cells of the test culture were qualitatively evaluated using a software module for automatic pixel calculation with a histochemical reaction color palette.

\section{Results and discussion}

The data of ${ }^{1} \mathrm{H} /{ }^{13} \mathrm{C}$ NMR spectra and X-ray analysis of carbothioamides HL1, HL2 and their complexes as well as parameters for assessing their biological activity, such as IC50 and their DNA binding ability, were reported previously in ref. [1]. In continuation of that work, this paper reports the processes of complex formation in solutions based on UV-Vis spectra in order to establish detailed conditions of complex formation and compare the spectral characteristics of compounds with each other both in solution and in the solid state. In addition, to study the spectral characteristics of the solid state of the synthesized cisplatin analogues, we present the IR and diffuse reflection spectra.
$U V-V i s$ and diffuse reflection spectra of carbothioamides $H L^{1}, H L^{2}$ and complexes I-IV based on them

The results showed that the UV-Vis spectra of both carbothioamides are similar and consist of lowintensity shoulder-type absorption bands at 33620 and $34220 \mathrm{~cm}^{-1}$, which are due to intraligand $\pi \rightarrow \pi^{*}$ and $n \rightarrow \pi^{*}$ electron transitions with the contribution of the multiple bond $(\mathrm{C}=\mathrm{S})$ of the carbothioamide moiety, respectively. The observed absorption difference $\left(\Delta v=600 \mathrm{~cm}^{-1}\right)$ is associated with the influence of the nature of the substituent in the $\mathrm{HL}^{1}$ and $\mathrm{HL}^{2}$ molecules (Fig. 2, Table 1) [2,12].

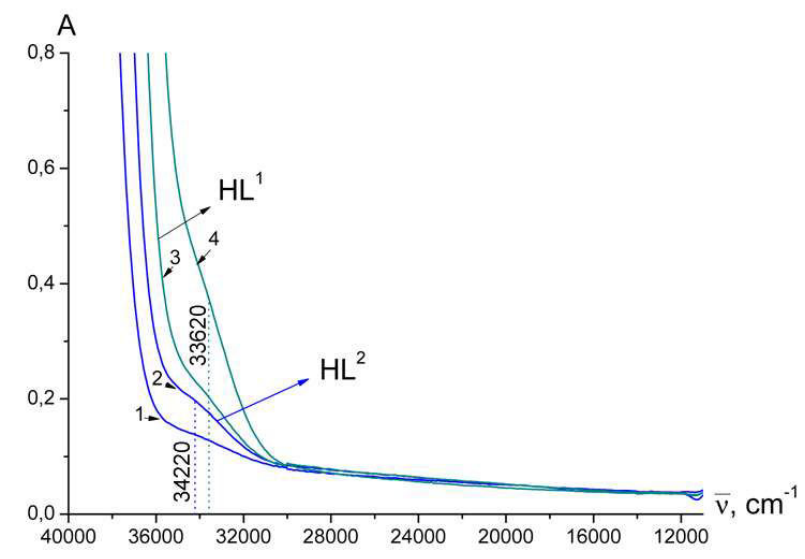

Fig. 2. UV-Vis spectra of carbothioamides $\mathrm{HL}^{1}, \mathrm{HL}^{2}$ in a mixture DMF:ethanol $=2: 1\left(1,2-\mathrm{C}_{(\mathrm{HL} 2)}=1 \cdot 10^{-4} \mathrm{M}\right.$; $\left.3,4-\mathrm{C}_{(\mathrm{HL} 1)}=1 \cdot 10^{-4} \mathrm{M}\right)$

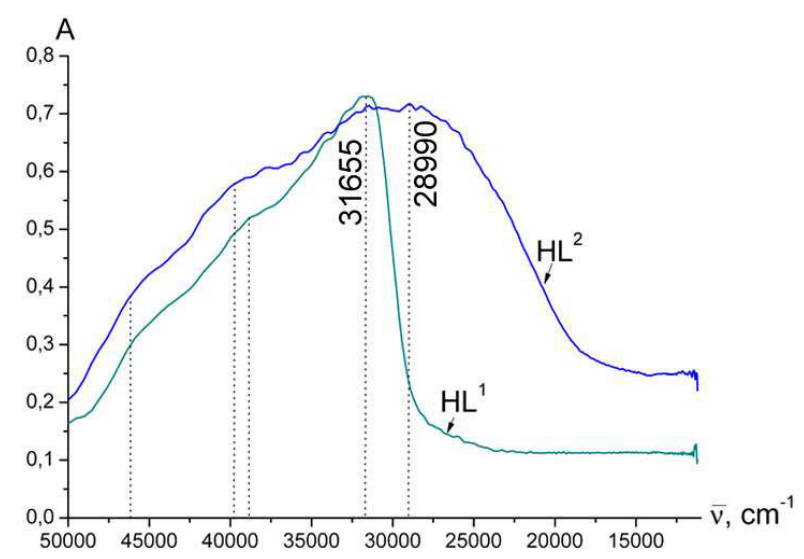

Fig. 3. Diffuse reflection spectra of carbothioamides $\mathrm{HL}^{1}, \mathrm{HL}^{2}$

Unlike the UV-Vis spectra, the diffuse reflection spectra of $\mathrm{HL}^{1}$ and $\mathrm{HL}^{2}$ show several maxima at $46154,38860,31655$ and $46154,39790,31655$, $28990 \mathrm{~cm}^{-1}$, respectively. These maxima are related 
UV-Vis and diffuse reflection spectra data $\left(\mathrm{n}, \mathrm{cm}^{-1}\right)$ of $\mathrm{HL}^{1}, \mathrm{HL}^{2}$ and complexes $\mathrm{I}-\mathrm{IV}$

\begin{tabular}{l|c|c|c|c|c|c}
\hline \multirow{2}{*}{ Compound } & \multicolumn{3}{|c|}{ Assignments in UV-Vis } & \multicolumn{2}{c}{ Assignments in Diffuse reflection spectra } \\
\cline { 2 - 7 } & $\pi \rightarrow \pi^{*}, \mathrm{n} \rightarrow \pi^{*}$ & $\begin{array}{c}(\mathrm{LMCT})^{1} \\
\text { transitions }\end{array}$ & $\mathrm{dd}$ & $\pi \rightarrow \pi^{*}, \mathrm{n} \rightarrow \pi^{*}$ & $\begin{array}{c}(\mathrm{LMCT})^{1} \\
\text { transitions }\end{array}$ & $\mathrm{dd}$ \\
\hline $\mathrm{HL}^{1}$ & 33620 & - & - & $46154,38860,31655$ & - & - \\
\hline Complex I & 36890 & 30150,26325 & 21273 & $46000,38800,29937$ & 24882 & 20065 \\
\hline Complex II & \multicolumn{2}{|c|}{32680} & 26100 & $46000,38800,29937$ & 26100 & 18500 \\
\hline $\mathrm{HL}^{2}$ & 34220 & - & - & $46154,39790,31655,28990$ & - & - \\
\hline Complex III & 36565 & 34200,28112 & 21100 & $45087,38555,31355$ & 24822 & 21245 \\
\hline Complex IV & \multicolumn{2}{|c|}{32455} & 25450 & $45087,38555,31355$, & 26112 & 18655 \\
\hline
\end{tabular}

Note: ${ }^{1}-(\mathrm{LMCT})$ - ligand-to-metal charge-transfer.

to intraligand $\pi \rightarrow \pi^{*}$ and $\mathrm{n} \rightarrow \pi^{*}$ electron transitions with contributions of multiple bonds of the allyl moiety and carbothioamide group (Fig. 3, Table 1). The both spectra are characterized by the presence of a broad and low pronounced maximum at $28990 \mathrm{~cm}^{-1}$ in the $\mathrm{HL}^{2}$ spectrum and $\Delta v_{2}=930 \mathrm{~cm}^{-1}$, which is related to the influence of the nature of the substituent and, as a consequence, to the different electron density distribution in the organic ligand molecule. In UV-Vis spectra, the absorption in the ultraviolet region from 50000 to $36000 \mathrm{~cm}^{-1}$ overlaps the absorption of solvent (DMF).

The UV-Vis spectra of complexes I-IV in a mixture DMF:ethanol=2:1 mainly consist of absorption bands responsible for ligand-to-metal charge-transfer (LMCT) and d-d electron transitions in the metal ion (Figs. 4, 5, Table 1).

The broad absorption band at $32680 / 32455 \mathrm{~cm}^{-1}$ in the spectrum of the complexes of platinum II and IV corresponds to the overlap of the intraligand electron transitions $\pi \rightarrow \pi^{*}$ and $n \rightarrow \pi^{*}$ of the carbothioamide group with the charge transfer from ligand to metal. The absorption bands of LMCT transitions and dd-electron transitions are visualized separately in the spectrum of palladium complexes I and III, which is related to the nature of the metal. In this case, the absorption bands of intraligand electronic transitions $\pi \rightarrow \pi^{*}$ and $n \rightarrow \pi^{*}$ undergo a significant hypochromic shift with respect to the ligands themselves. These changes are due to the presence of a coordination link [13].

Unlike UV-Vis spectra, the diffuse reflection spectra exhibit several highs in the curves which are related with both intraligand $\pi \rightarrow \pi^{*}$ and $n \rightarrow \pi^{*}$ electron transitions of carbothioamide group as well as LMCT and dd-electron transitions (Figs. 6, 7, Table 1).

To analyze the complex formation in ethanol solution, the dependence of the absorbance on the ligand concentration was studied (Figs. 8, 9). Unlike the UV-Vis spectra of the synthesized complexes dissolved in a mixture DMF:ethanol=2:1 (Figs. 4, 5), the UV-Vis spectra of ethanol solutions of

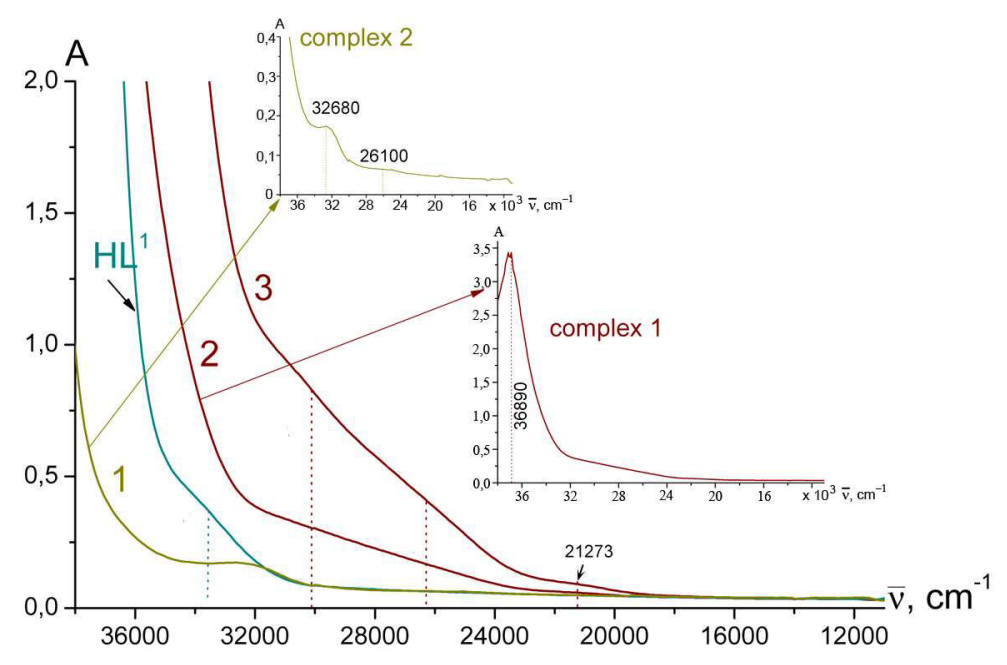

Fig. 4. UV-Vis spectra of carbothioamide $\mathrm{HL}^{1}$ and complexes I and II in a mixture DMF:ethanol=2:1 (curves $1-3$ show the spectra for different concentrations of complexes, $1 \cdot 10^{-3}$ and $1 \cdot 10^{-4} \mathrm{M}$ ) 


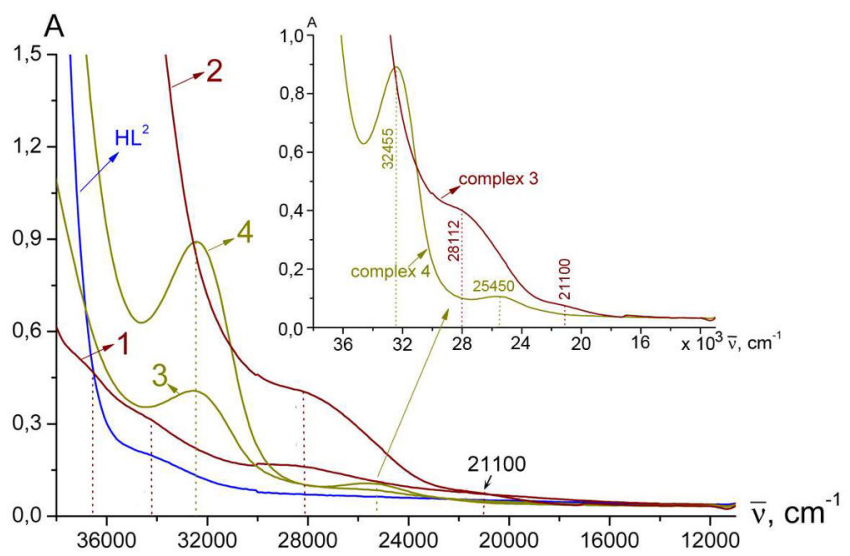

Fig. 5. UV-Vis spectra of carbothioamide $\mathrm{HL}^{2}$ and complexes III and IV in a mixture DMF:ethanol=2:1 (curves 1-4 show the spectra for different concentrations of complexes, $1 \cdot 10^{-3}$ and $1 \cdot 10^{-4} \mathrm{M}$ )

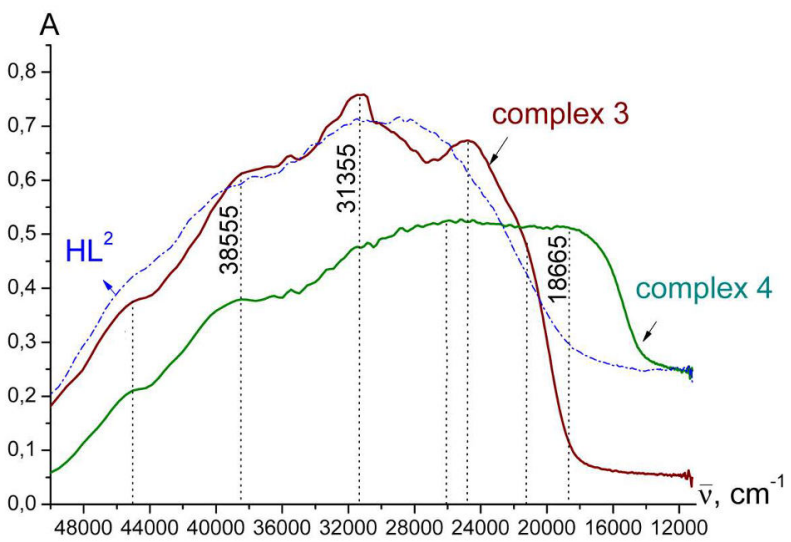

Fig. 6. Diffuse reflection spectra of $\mathrm{HL}^{2}$ and complexes III and IV

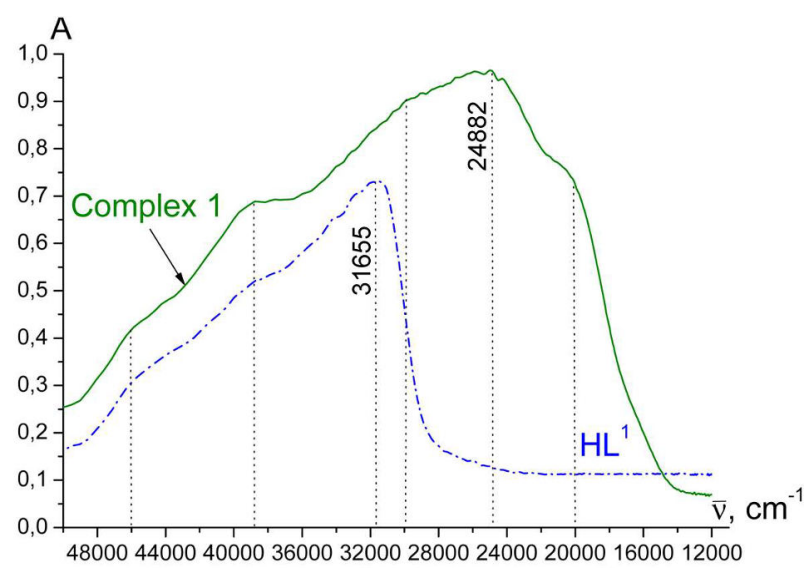

Fig. 7. Diffuse reflection spectra of $\mathrm{HL}^{1}$ and complex I
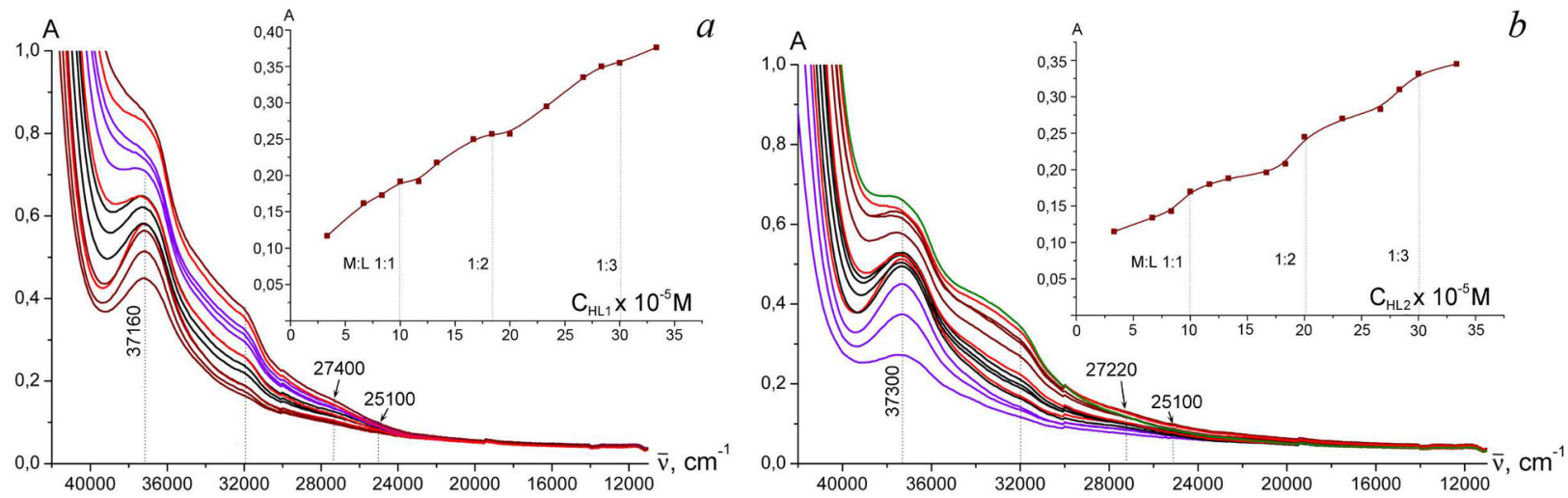

Fig. 8. The UV-Vis spectra and titration curves of complexes I (a), III (b)

complexes (obtained «in situ») contain the absorption bands of intraligand $\pi \rightarrow \pi^{*}$ and $n \rightarrow \pi^{*}$ electron transitions (at 37160/38200, 36600/37300/38370, $36600,31950 / 32700 / 32000 / 32500)$, LMCT (at $27400 / 27700 / 27220 / 27700 /$ ) and dd (at 25100/ $25700 / 25100 / 25900) \mathrm{cm}^{-1}$. These absorption bands show a hypochromic shift relative to the previous spectra, which is caused by the different nature of the solvent. The results showed that the titration curves have slightly pronounced inflections at the ratio of the components $\mathrm{M}: \mathrm{L}=1: 1,1: 2$ and $1: 3$, indicating possible coordination of the ligands in 

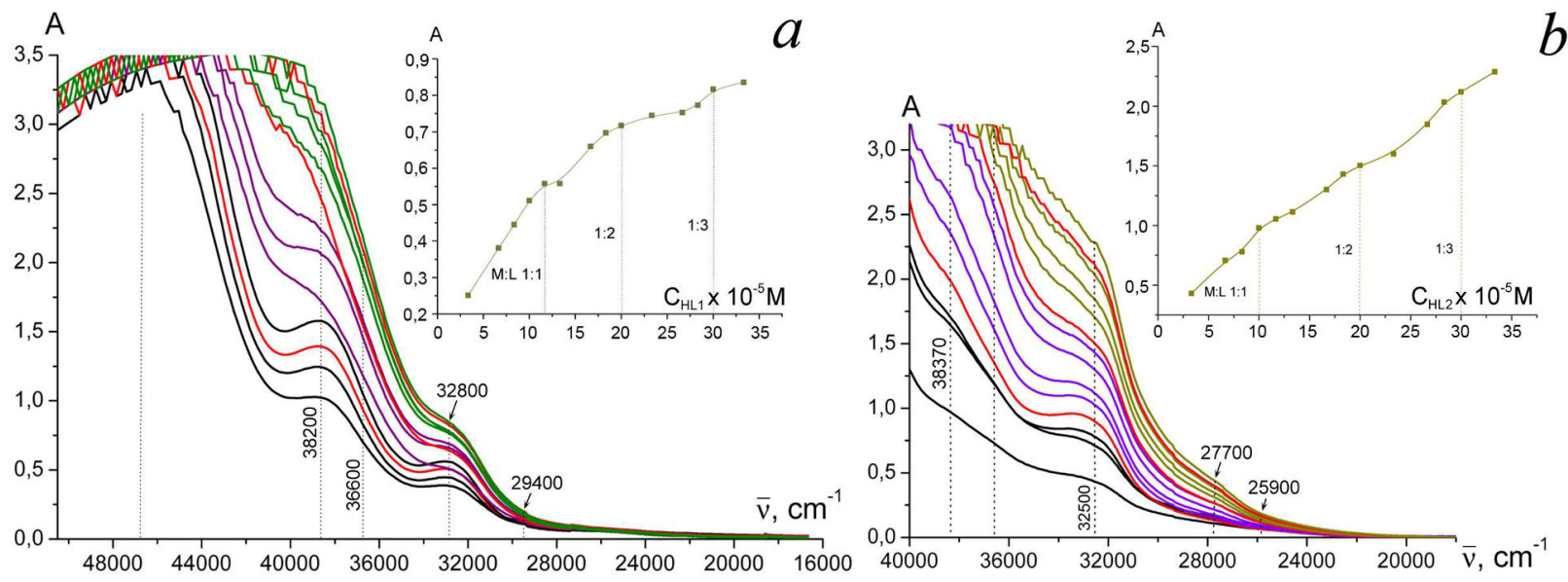

Fig. 9. The UV-Vis spectra and titration curves of complexes II (a), IV (b)
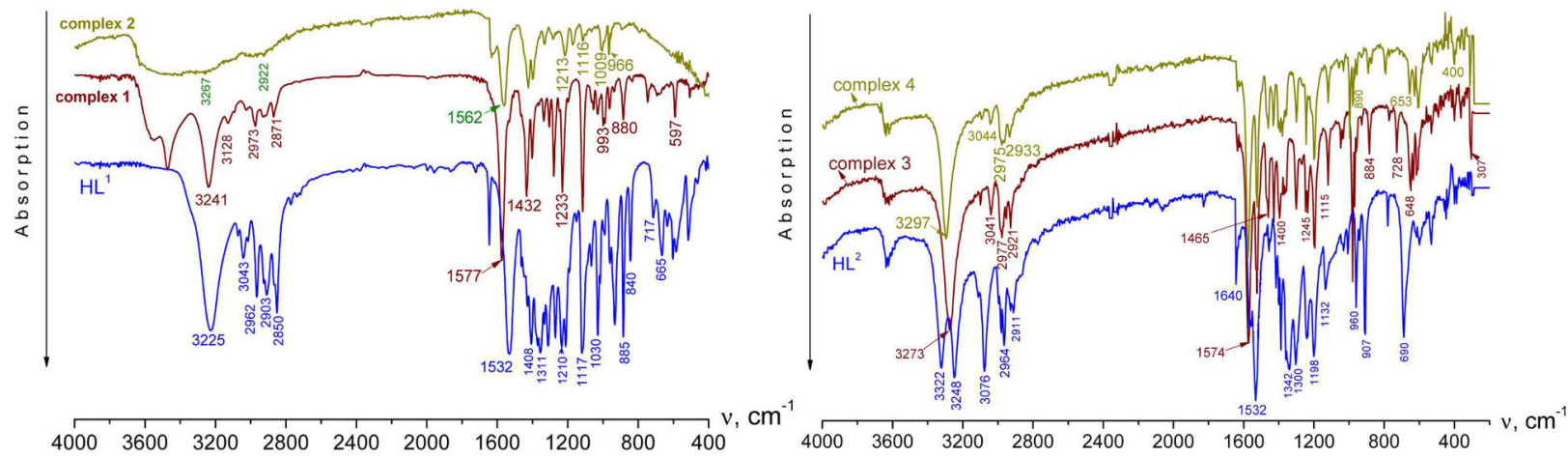

Fig. 10. IR spectra of carbothioamides $\mathrm{HL}^{1}, \mathrm{HL}^{2}$ and complexes I-IV

solution in both helate and non-chelate ways only through the atoms of sulfur of the carbothioamide group similar to the compounds studied previously [14]. However, complexes with such coordination were not obtained in the solid state, which can be caused by the strong trans-influence of the allyl moiety that destabilizes the bond with the «soft» atom in the trans-position of coordination polyhedron.

IR spectra of carbothioamides $H L^{1}, H L^{2}$ and complexes $I-I V$ based on them

The assignment of the bands in the IR spectra of allylthioureas and their metal complexes (Fig. 10) was performed at BP86/MCP-TZP level of theory (Tables 2-4). In the high-frequency region of the IR spectra of $\mathrm{HL}^{1}$ and $\mathrm{HL}^{2}$, the absorption bands referring to stretching vibrations of $v(\mathrm{NH})$, $v_{\text {as }}\left(\mathrm{CH}_{2}\right)_{\text {morph }} / v_{\text {as }}\left(\mathrm{CH}_{3}\right)_{\text {tert-but }}, v_{\mathrm{s}}\left(\mathrm{CH}_{2}\right)_{\text {morph }} / v_{\mathrm{s}}\left(\mathrm{CH}_{3}\right)_{\text {tert-but }}$ and $n(C H)_{\text {allyl }}$ are present. In the IR spectra of complexes, these bands are shifted to higher frequencies by $\Delta v=+16 / 42 / 25 / 49 \mathrm{~cm}^{-1}(v(\mathrm{NH}))$, $+85 / 45 \mathrm{~cm}^{-1}\left(v_{\text {as }}\left(\mathrm{CH}_{2}\right)_{\text {morph }} / \mathrm{v}_{\mathrm{as}}\left(\mathrm{CH}_{3}\right)_{\text {tert-but }}\right)$ and $11 / 20 \mathrm{~cm}^{-1}\left(v(\mathrm{CH})_{\text {allyl }}\right)$, which is caused by the involvement of carbothioamide and allyl moieties in the formation of a coordination bond with a metal ion. In this case, the stretching vibrations of two $\mathrm{NH}$ groups in the spectrum of free $\mathrm{HL}^{2}$ ligand are manifested by two absorption bands, and they merge in the complexes into one intense rather broad absorption band with an offset of $25-50 \mathrm{~cm}^{-1}$ (Fig. 10). The corresponding high-frequency shift $\left(\Delta v=45 / 30 / 11 / 16 \mathrm{~cm}^{-1}\right)$ is also subjected to stretching and bending vibrations $v_{\text {as }}(\mathrm{NCN})+\delta(\mathrm{NH})$ (Tables 3 and 4). At the same time, the vibrations $v(\mathrm{CS})$ undergo a low-frequency shift by $72 / 37 \mathrm{~cm}^{-1}$ (Table 4), which is characteristic of the chelate coordination of the carbothioamide group with participation $\mathrm{C}=\mathrm{S}$ in the formation of a metal cycle. Cytostatic effect of carbotioamid Pd(II) and Pt(II) $\pi$-complexes on the meristem cells of Allium cepa $L$. compared to cisplatin

Many antitumor agents either directly interact with DNA (doxorubicin, cisplatin, etc.) or with the mitotic apparatus (for example, vinblastine blocks the tubulin and arrests the cellular division in metaphase), leading to various changes and 
Table 2

Experimental and calculated frequencies of the main absorption bands in the IR spectra of $\mathrm{HL}^{1}$ and $\mathrm{HL}^{2}\left(\mathrm{~cm}^{-1}\right)$

\begin{tabular}{|c|c|c|c|c|}
\hline \multicolumn{2}{|c|}{$\mathrm{HL}^{1}$} & \multicolumn{2}{|c|}{$\mathrm{HL}^{2}$} & \multirow{2}{*}{ Assignment $\left(\mathrm{HL}^{1} / \mathrm{HL}^{2}\right)^{*}$} \\
\hline Experimental & Calculated & Experimental & Calculated & \\
\hline 3225 & 3505 & 3322,3248 & 3493 & $v(\mathrm{NH}) / v(\mathrm{NH})$ \\
\hline 3043 & 3018 & 3076 & 3042 & $v_{\text {as }}\left(\mathrm{CH}_{2}\right)_{\text {morph }} / v_{\text {as }}\left(\mathrm{CH}_{3}\right)_{\text {tert-but }}$ \\
\hline $\begin{array}{c}2962,2903 \\
2850 \\
\end{array}$ & $\begin{array}{c}2936 \\
2915,2902 \\
\end{array}$ & \begin{tabular}{|l|}
2985,2964, \\
2926,2911 \\
\end{tabular} & 2959 & $v_{\mathrm{s}}\left(\mathrm{CH}_{2}\right), v(\mathrm{CH})_{\text {allyl }} / v_{\mathrm{s}}\left(\mathrm{CH}_{3}\right), v(\mathrm{CH})_{\text {allyl }}$ \\
\hline 1647 & 1650 & 1640 & 1656 & $v(\mathrm{C}=\mathrm{C}) / v(\mathrm{C}=\mathrm{C})$ \\
\hline 1532 & 1534 & 1563,1532 & 1535 & $v_{\mathrm{as}}(\mathrm{NCN})+\delta(\mathrm{NH}) / v(\mathrm{NCN})+\delta(\mathrm{NH})+\delta_{\mathrm{as}}\left(\mathrm{CH}_{3}\right)$ \\
\hline 1470,1432 & - & 1454,1420 & 1439 & $\delta_{\mathrm{s}}\left(\mathrm{CH}_{3}\right)$ \\
\hline 1408 & 1385 & 1388 & 1395 & $v_{\mathrm{as}}(\mathrm{SCN})+\omega\left(\mathrm{CH}_{2}\right) / v_{\mathrm{as}}(\mathrm{NCN})+\omega\left(\mathrm{CH}_{2}\right)$ \\
\hline 1355 & 1339 & 1342 & 1338 & $v_{\mathrm{s}}(\mathrm{NCN})+v(\mathrm{CS})+t\left(\mathrm{CH}_{2}\right) / v_{\mathrm{as}}(\mathrm{NCN})+\delta(\mathrm{NH})+\omega\left(\mathrm{CH}_{2}\right)$ \\
\hline 1311,1270 & 1275 & 1300,1237 & $1300,1233,1251$ & $v_{\mathrm{as}}(\mathrm{NCN})+t\left(\mathrm{CH}_{2}\right) / v_{\mathrm{s}}(\mathrm{NCN})+v(\mathrm{CS})+\delta(\mathrm{NH})+t\left(\mathrm{CH}_{2}\right)$ \\
\hline 1236,1210 & 1229 & 1200 & 1229 & $v_{\mathrm{as}}(\mathrm{NCN})+v(\mathrm{CS})+t\left(\mathrm{CH}_{2}\right) / v\left(\mathrm{~N}-\mathrm{C}\left(\mathrm{CH}_{3}\right)_{3}\right)+v_{\mathrm{s}}(\mathrm{NCN})+v(\mathrm{CS})$ \\
\hline 1117 & 1114 & 1132 & 1164 & $v_{\mathrm{as}}(\mathrm{COC})_{\mathrm{morph}} / \mathrm{v}\left(\mathrm{N}-\mathrm{CH}_{2}\right)+v_{\mathrm{s}}(\mathrm{NCN})+\mathrm{v}(\mathrm{CS})$ \\
\hline 1030 & 1050 & 1033 & 1055 & $v_{\mathrm{s}}(\mathrm{COC})+v_{\mathrm{s}}(\mathrm{CNC})_{\operatorname{morph}}+v(\mathrm{CN}) / v(\mathrm{CN})+\rho\left(\mathrm{CH}_{3}\right)+t\left(=\mathrm{CH}_{2}\right)$ \\
\hline 961,935 & 981,949 & 960 & 968 & $v(\mathrm{CC})+v(\mathrm{CS}) ; \omega\left(=\mathrm{CH}_{2}\right) / v\left(\mathrm{~N}-\mathrm{C}\left(\mathrm{CH}_{3}\right)_{3}\right)+\rho\left(\mathrm{CH}_{3}\right)$ \\
\hline 885,840 & 899 & 907 & 949 & $\omega\left(=\mathrm{CH}_{2}\right)$ \\
\hline $717,665,603$ & 648,616 & 690,602 & 680,597 & $v_{\mathrm{s}}(\mathrm{COC})+v(\mathrm{CS})+v_{\mathrm{s}}(\mathrm{CNC})_{\operatorname{morph}} / v(\mathrm{CS})+\delta(\mathrm{CNC})+t\left(=\mathrm{CH}_{2}\right)$ \\
\hline 517,461 & - & 538,460 & 548,443 & $\pi\left(\mathrm{S}-\mathrm{C}-\mathrm{N}_{2}\right) / \pi(\mathrm{NH})$ \\
\hline
\end{tabular}

Note: ${ }^{*} v-$ stretching, $\delta$ - in-plane bending, $\mathrm{t}-$ twisting, $\omega$ - wagging, $\rho$ - rocking, $\pi$ - out-of-plane bending as - asymmetric, and $\mathrm{s}-$ symmetric.

Table 3

Experimental and calculated frequencies of the main absorption bands in the IR spectra of $\operatorname{Pd}\left(\mathrm{HL}^{1}\right) \mathrm{Cl}_{2}$ and $\operatorname{Pt}\left(\mathrm{HL}^{1}\right) \mathrm{Cl}_{2}\left(\mathrm{~cm}^{-1}\right)$

\begin{tabular}{|c|c|c|c|c|}
\hline \multicolumn{2}{|c|}{$\mathrm{Pd}\left(\mathrm{HL}^{1}\right) \mathrm{Cl}_{2}$} & \multicolumn{2}{|c|}{$\mathrm{Pt}\left(\mathrm{HL}^{1}\right) \mathrm{Cl}_{2}$} & \multirow{2}{*}{ Assignment } \\
\hline Experimental & Calculated & Experimental & Calculated & \\
\hline 3241 & 3504 & 3267 & 3507 & $v(\mathrm{NH})$ \\
\hline 3128,3027 & 3024 & 3088,3024 & 3065,3034 & $v_{\text {ass }}\left(\mathrm{CH}_{2}\right)$ \\
\hline $2973,2920,2871$ & 2936 & $2965,2922,2880$ & 2954,2903 & $v_{s}\left(\mathrm{CH}_{2}\right)$ \\
\hline 1577 & 1554 & 1562 & 1559 & $v_{\mathrm{as}}(\mathrm{NCN})+\delta(\mathrm{NH})$ \\
\hline 1432 & 1442 & 1432 & 1448 & $v_{\mathrm{s}}(\mathrm{NCN})+\delta(\mathrm{NH})$ \\
\hline 1400 & 1415 & 1400 & 1419 & $v_{\mathrm{s}}(\mathrm{NCN})+v(\mathrm{CS})+\omega\left(\mathrm{CH}_{2}\right)$ \\
\hline 1336 & 1365 & 1335 & 1351 & $v_{\mathrm{s}}(\mathrm{NCN})+v(\mathrm{CS})+\omega\left(\mathrm{CH}_{2}\right)$ \\
\hline 1277 & 1298 & 1290 & 1288 & $v_{\mathrm{as}}(\mathrm{NCN})+v(\mathrm{CN})+\mathrm{t}\left(\mathrm{CH}_{2}\right)$ \\
\hline 1233 & 1241 & 1213 & 1236 & $v_{\mathrm{s}}(\mathrm{NCN})+v(\mathrm{CS})+\mathrm{t}\left(\mathrm{CH}_{2}\right)$ \\
\hline 1110 & 1115 & 1116 & 1116 & $\mathrm{v}_{\mathrm{as}}(\mathrm{COC}+\mathrm{CNC})_{\mathrm{morph}}$ \\
\hline 1058 & 1078 & 1064 & 1075 & $v_{\mathrm{as}}(\mathrm{COC})_{\operatorname{morph}}+\rho\left(\mathrm{CH}_{2}\right)$ \\
\hline 1033 & 1043 & 1045 & 1048 & $v(\mathrm{CN})+\delta(\mathrm{COC}, \mathrm{CNC})_{\operatorname{morph}}$ \\
\hline 993 & 1002 & 1009 & 987 & $v(\mathrm{CN})+v(\mathrm{CS})+\rho\left(\mathrm{CH}_{2}\right)$ \\
\hline 965 & 979 & 968 & 949 & $\mathrm{t}\left(=\mathrm{CH}_{2}\right)$ \\
\hline 880 & 891 & 890 & 886 & $v_{\mathrm{s}}(\mathrm{COC}+\mathrm{CNC})_{\operatorname{morph}}+v(\mathrm{CS})+v(\mathrm{CC})$ \\
\hline 750 & 755 & - & - & $\mathrm{t}\left(=\mathrm{CH}_{2}\right)$ \\
\hline 597 & 599 & 591 & 604 & $\pi\left(\mathrm{S}-\mathrm{C}-\mathrm{N}_{2}\right)+\delta(\mathrm{COC})_{\mathrm{mor}}$ \\
\hline
\end{tabular}

P.V. Borovyk, S.I. Orysyk, H.H. Repich, A.F. Likhanov, A.M. Mishchenko, Yu.L. Zborovskii, V.V. Orysyk, L.G. Palchikovska, V.I. Pekhnyo, M.V. Vovk 
Experimental and calculated frequencies of the main absorption bands in the IR spectra of $\operatorname{Pd}\left(\mathrm{HL}^{2}\right) \mathrm{Cl}_{2}$ and $\operatorname{Pt}\left(\mathrm{HL}^{2}\right) \mathrm{Cl}_{2}\left(\mathrm{~cm}^{-1}\right)$

\begin{tabular}{|c|c|c|c|c|}
\hline \multicolumn{2}{|c|}{$\mathrm{Pd}\left(\mathrm{HL}^{2}\right) \mathrm{Cl}_{2}$} & \multicolumn{2}{|c|}{$\mathrm{Pt}\left(\mathrm{HL}^{2}\right) \mathrm{Cl}_{2}$} & \multirow{2}{*}{ Assignment } \\
\hline Experimental & Calculated & Experimental & Calculated & \\
\hline 3273 & 3509 & 3297 & 3505 & $v(\mathrm{NH})$ \\
\hline 3099,3041 & 3049 & 3094,3044 & 3050 & $\mathrm{v}_{\mathrm{as}}\left(\mathrm{CH}_{3}\right)$ \\
\hline $2977,2951,2921$ & 2960 & 2975,2933 & 2960 & $\mathrm{v}_{\mathrm{s}}\left(\mathrm{CH}_{3}\right)$ \\
\hline 1574 & 1581 & 1579 & 1583 & $v_{\mathrm{as}}(\mathrm{NCN})+\delta(\mathrm{NH})$ \\
\hline 1530 & 1539 & 1529 & 1545 & $v_{\mathrm{s}}(\mathrm{NCN})+v(\mathrm{CS})+\delta(\mathrm{NH})+\delta_{\mathrm{as}}\left(\mathrm{CH}_{3}\right)$ \\
\hline 1465 & 1476 & 1460 & 1495 & $\delta(\mathrm{NH})+\delta\left(\mathrm{CH}_{2}\right)$ \\
\hline 1433 & 1447 & 1433 & 1434 & $v_{\mathrm{as}}(\mathrm{NCN})+\delta(\mathrm{NH})+\delta_{\mathrm{s}}\left(\mathrm{CH}_{3}\right)$ \\
\hline 1400 & 1388 & 1395 & 1397 & $v_{\mathrm{as}}(\mathrm{NCN})+\delta(\mathrm{NH})+\delta_{\mathrm{s}}\left(\mathrm{CH}_{3}\right)+\omega\left(\mathrm{CH}_{2}\right)$ \\
\hline 1365 & 1332 & 1363 & 1339 & $v_{\mathrm{s}}(\mathrm{NCN})+v(\mathrm{CS})+\delta(\mathrm{NH})+t\left(\mathrm{CH}_{2}\right)$ \\
\hline 1246 & 1246 & 1245 & 1257 & $v_{\mathrm{s}}(\mathrm{NCN})+v(\mathrm{CS})+v(\mathrm{CC})+t\left(\mathrm{CH}_{2}\right)$ \\
\hline 1200 & 1219 & 1200 & 1220 & $v_{\mathrm{s}}(\mathrm{NCN})+v(\mathrm{CS})+v(\mathrm{CN})+\rho\left(\mathrm{CH}_{3}\right)$ \\
\hline 1115 & 1138 & 1115 & 1133 & $v(\mathrm{CS})+v(\mathrm{CN})+\delta(\mathrm{NCN})$ \\
\hline 981,970 & $995,981,975$ & 1002,975 & 1012 & $v(\mathrm{CS})+\delta(\mathrm{NCN})+\omega\left(=\mathrm{CH}_{2}\right)+\rho\left(\mathrm{CH}_{2}\right)$ \\
\hline 960 & 979 & 957 & 979 & $\rho\left(\mathrm{CH}_{3}\right)$ \\
\hline 884 & 898 & 890 & 899 & $v(\mathrm{CS})+\delta(\mathrm{NCN})$ \\
\hline- & - & 796 & 816 & $v(\mathrm{CS})+t\left(=\mathrm{CH}_{2}\right)$ \\
\hline 728 & 741 & - & - & $v(\mathrm{CS})+t\left(=\mathrm{CH}_{2}\right)+\rho\left(\mathrm{CH}_{2}\right)$ \\
\hline 648 & 675 & 653 & 679 & $v(\mathrm{CS})+\delta_{\text {ring }}$ \\
\hline 615 & 640 & 610 & 626 & $\pi\left(\mathrm{S}-C-\mathrm{N}_{2}\right)$ \\
\hline 535 & 540 & 539 & 556 & $\pi(\mathrm{NH})+\delta_{\text {ring }}$ \\
\hline
\end{tabular}

disruptions in daughter cells. The genetic damage manifests as small spherical particles outside the nuclear membrane in the form of micronucleus and/ or chromosomal abnormalities in cells.

The effect of cytostatic agents on the interphase cells of apical meristems was evaluated by the state of chromatin. Staining DNA by Feulgen reaction prevents the nonspecific coloring and allows analyzing the concentration and state of DNA by light and fluorescent microscopy. Allium cepa cells have 16 chromosomes $(2 n=16)$ which are easily stained.

The intensity of specific DNA staining is inversely related to the degree of condensation. The compactly folded heterochromatin of interphase nuclei is transcriptionally inactive and is located predominantly at the periphery of the nucleus. The less condensed chromatin (euchromatin) is transcriptionally active. It is the ratio of hetero- and euchromatin in nuclei that creates the effect of diffuse staining of DNA in nuclei.

Thus, we observed the specific action of studied complex compounds on the chromatin. Palladium complexes I and III induced a relatively increasing ratio of condensed chromatin in interphase cells. That points to the partial inactivation of euchromatin in chromosomes causing certain transcription processes in cells to slow down or stop altogether. Considering that the apical meristem cells of Allium cepa were exposed to compounds for four hours and the average time of mitosis in that culture is two to three hours, most cells were exposed to the cytostatic effect in interphase.

The cells, which entered the process of mitosis before the penetration of cytostatics into the cytoplasm, were affected differently. For example, the mitotic tissue index did not decrease significantly in the first hours after exposure to cisplatin. Functional disorders of karyokinesis were detected only in the duration of the phases (Fig. 11). Cisplatin (V) abnormally increased the duration of prophase and telophase. In the condensed state, the intensity of damage of DNA molecules is significantly reduced. However, the ability of cytostatics to interact with proteins of the cytoskeleton still leads to the disruption of the spatial orientation of chromosomes in metaphase. Under the action of cisplatin and its analogue (II), cells in the meta- and anaphase stages almost did not occur. Under normal conditions, the latter are the shortest in the course of the mitotic cycle, being energy consuming and requiring the proper arrangement of cellular structures. Increasing 
entropy complicates the transition of cells from the prometaphase to metaphase and further to anaphase.

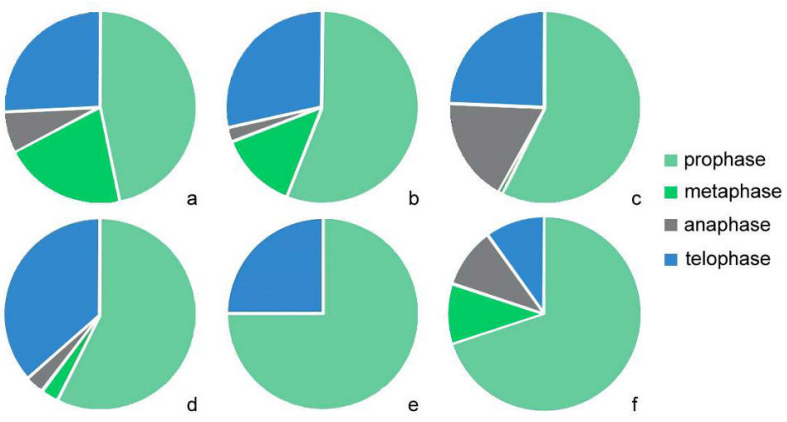

Fig. 11. Effect of cisplatin and its analogues on the duration of phases of mitosis (Allium test): $\mathrm{a}-$ control, $\mathrm{b}-\mathrm{f}-$ compounds I (b), II (c), III (d), V (e), IV (f)

It is known that complex compounds of platinum group [6-8] and some other metals, such as rhenium [15], are capable of forming coordination bonds with the nitrogenous bases of DNA, which allows scientists to develop novel cytostatics. Numerical bonds between molecules cause chromatin dispersion. Dispersion and disruption of heterochromatin under the action of palladium-based preparations was detected in cells during mitosis (Fig. 12).

In anaphase, bridges are formed in the divergence of chromosomes due to the numerical cross-links between the telomeric regions of the daughter chromatids (Fig. 12,a, 12,c). Chromosomes lose their typical morphology, becoming homogeneous masses of proteins and DNA molecules. The proteins of division spindle contract and the chromatin loses its compact supercoiling structure, breaking into fragments and remaining in the form of thin filaments at the division equator. A similar process was observed in cells, in which chromosomes diverged to form a mitotic plate characteristic of k-mitoses. The heterochromatin is separated on the surface of chromosomes, which is evidence of disruption of its ordered structure (Fig. 12,b).

Similar but less pronounced signs of structural abnormalities of chromosomes were found in cells under the action of cisplatin (Fig. 12,e). Using fluorescence microscopy to study prometaphase cells, we found an increase in the fluorescence brightness along the contour of chromosome sections.

Under the influence of compound II, increased condensation of chromatin was observed in the interphase nuclei near the nuclear membrane. The compaction of cytoplasmic proteins was also revealed,

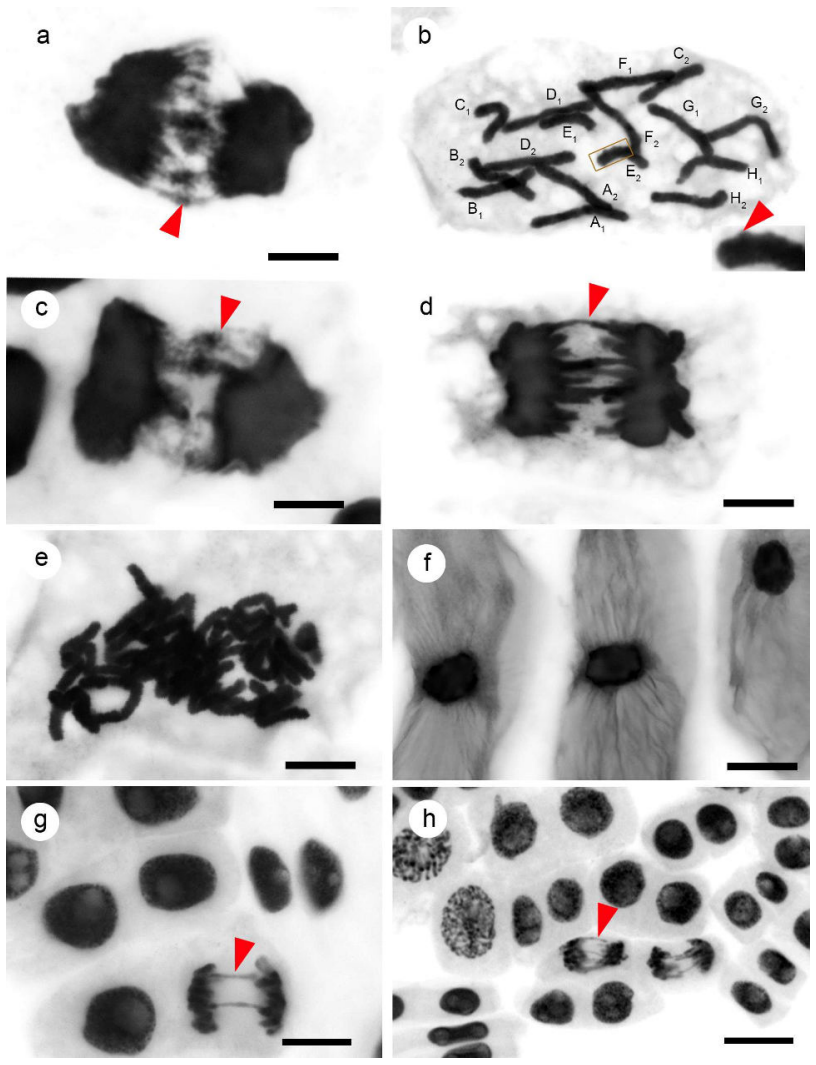

Fig. 12. Disruption of mitosis in Allium cepa cells: a, $d-$ formation of numerous bridges with fragmentation of chromosomes at anaphase; b, $\mathrm{c}$ - dispersion of chromatin on the surface of chromosomes; $d, e-$ dispersion of the surface of chromosomes and disruption of their spatial orientation in protoplast under the action of cisplatin; $\mathrm{f}-$ condensation and dispersion of chromatin in interphase nuclei under the action of platinum-containing cytostatics; arrows indicate signs of chromatin dispersion under the influence of palladiumcontaining compounds I $(a, b)$ and III (c), formation of bridges under the action of compound IV $(\mathrm{g}-\mathrm{h})$; DNA staining by cold hydrolysis according to Feuglen; (inverted image); scale bars: $\mathrm{a}-\mathrm{e}-10 \mu \mathrm{m}, \mathrm{f}-\mathrm{g}-20 \mu \mathrm{m}, \mathrm{h}-30 \mu \mathrm{m}$

which was accompanied by an increase in the fluorescence intensity in the red region of the spectrum (605-620 nm) (Fig. 12,f).

The last of the investigated compounds caused minor disturbances in the division of cells that were associated with the formation of numerous bridges (Fig. 12,g, 12,h). The anaphase chromosomes can rupture when they diverge with the formation of micronuclei and consequent loss of a large amount of hereditary information and cell death. However, complex IV had a less pronounced mutagenic effect compared to all other studied preparations. The number of cells with chromosome morphology disorders and anomalies of mitosis did not exceed 


\section{$0.48-1.0 \%$.}

\section{Conclusions}

In order to predict the behavior of $\pi$-complex compounds I-IV in biological media, their state in solutions was studied by spectral methods. It is shown that the electronic absorption and diffuse reflection spectra of complexes consist of absorption bands corresponding to the transitions with charge transfer from the ligand to the metal, dd-electron transitions and intraligand $\pi \rightarrow \pi^{*}$ and $n \rightarrow \pi^{*}$ electronic transitions with the contributions of multiple bonds of allyl moiety and carbothioamide group. Analysis of the titration curves showed the possible coordination of the ligands in solution in both chelate and nonchelate ways only through the atoms of sulfur of the carbothioamide group with molar ratio $\mathrm{M}: \mathrm{L}=1: 1$, $1: 2$ and 1:3. The complexes with such coordination are not obtained in solid state, which can be caused by the strong trans-influence of the allyl moiety that destabilizes the bond with the «soft» atom in the trans position. Theoretical quantum-chemical calculations of the IR spectra were also carried out. Their results are in good agreement with the experimental data of infrared spectroscopy.

It was found that cisplatin and its platinum and palladium-based analogues I-IV exert a specific cytostatic effect on Allium cepa meristem cells with high antiproliferative activity. Due to the formation of numerous cross-links of metal-containing preparations with DNA molecules and with nuclear proteins, chromatin is not compacting as normal. This leads to a disrupted cell cycle, a decreased mitotic index and anomalous cell division, which are usually followed by apoptosis.

Palladium-based complexes cause chromatin dispersion, which leads to significant abnormalities in the processes of karyokinesis. This causes the chromosomes to lose their typical structure and undergo fragmentation, mostly with loss of telomeric sites.

\section{Acknowledgements}

The work was performed with the financial support of Grant of the President of Ukraine (project number F84/247-2019).

\section{REFERENCES}

1. Synthesis, spectral characterization of novel Pd(II), Pt(II) $\pi$-coordination compounds based on $\mathrm{N}$-allylthioureas. Cytotoxic properties and DNA binding ability / Repich H.H., Orysyk V.V., Palchykovska L.G., Orysyk S.I., Zborovskii Yu.L., Vasylchenko O.V., Storozhuk O.V., Biluk A.A., Nikulina V.V., Garmanchuk L.V., Pekhnyo V.I., Vovk M.V. // J. Inorg. Biochem. - 2017. - Vol.168.
- P.98-106.

2. Synthesis, spectral characterization and DFT calculations of novel $\mathrm{Ag}(\mathrm{I}) \pi$-coordination polymeric complexes based on $\mathrm{N}$ allylmorpholine-4-carbothioamide / Orysyk S.I., Borovyk P.V., Repich H.H., Severynovska O.V., Zborovskii Yu.L., Mishchenko A.M., Orysyk V.V., Pekhnyo V.I., Vovk M.V. // J. Mol. Struct. - 2020. - Vol.1208. - Article No. 127866.

3. Antineoplastic, anti-metastatic and metabolic effects of newly synthesized platinum complexes / Biliuk A., Garmanchuk L., Skachkova O., Repich H., Orysyk S. // Bull. Taras Shevchenko Nat. Univ. Kyiv - Probl. Physiol. Funct. Regul. - 2017. - Vol.23. - No. 2. - P.69-75.

4. Pt (II) and Pd (II) complexes influence on spheroids growth of breast cancer cells / Bilyuk A.A., Storozhuk O.V., Kolotiy O.V., Repich H.H., Orysyk S.I., Garmanchuk L.V. // Biotechnol. Acta - 2017. - Vol.10. - No. 1. - P.61-67.

5. Kumar V., Chimni S.S. Recent developments on thiourea based anticancer chemotherapeutics // Anti-Cancer Agents Med. Chem. - 2015. - Vol.15. - No. 2. - P.163-175.

6. Anticancer activity of palladium-based complexes against triple-negative breast cancer / Vojtek M., Marques M.P.M., Ferreira I.M.P.L.V.O., Mota-Filipe H., Diniz C. // Drug Discovery Today. - 2019. - Vol.24. - No. 4. - P.1044-1058.

7. Kapdi A.R., Fairlamb I.J.S. Anti-cancer palladium complexes: a focus on $\mathrm{PdX}_{2} \mathrm{~L}_{2}$, palladacycles and related complexes // Chem. Soc. Rev. - 2014. - Vol.43. - No. 13. - P.4751-4777.

8. Synthesis, crystal structure, studies in solution and cytotoxicity of two new fluorescent platinum(II) compounds containing anthracene derivatives as a carrier ligand / MarquesGallego P., den Dulk H., Brouwer J., Kooijman H., Spek A.L., Roubeau O., Teat S.J., Reedijk J. // Inorg. Chem. - 2008. Vol.47. - No. 23. - P.11171-11179.

9. Kesharwani M.K., Brauer B., Martin J.M.L. Frequency and zero-point vibrational energy scale factors for double-hybrid density functionals (and other selected methods): can anharmonic force fields be avoided? // J. Phys. Chem. A. - 2015. - Vol.119. - P.1701-1714.

10. Barberio A., Voltolini J.C., Mello M.L. Standardization of bulb and root sample sizes for the Allium cepa test // Ecotoxicology. - 2011. - Vol.20(4). - P.927-935.

11. Pearse A.G. Histochemistry: theoretical and applied. London: Churchill, 1968. - $561 \mathrm{p}$.

12. Kazitsyna L.A., Kupletskaya N.B. The application of UV, IR and NMR spectroscopy in organic chemistry. - Moscow: Vysshaya Shkola, 1971. - 264 p. (in Russian).

13. Buslaeva T.M., Simanova S.A. State of platinum metals in hydrochlorideacidic and chlorides solutions. Palladium, platinum, rhodium and iridium. // Russ. J. Coord. Chem. 1999. - Vol.25. - No. 3. - P.165-176.

14. Effect of $\mathrm{Pd}(\mathrm{II})$ and $\mathrm{Ni}(\mathrm{II})$ coordination compounds with 4-amino-3-mercapto-5-methyl-1,2,4-triazole on the mitochondrial dehydrogenases activity / Orysyk S.I., Repich G.G., Andrushchenko O.O., Nikulina V.V., Orysyk V.V., Zborovskii Yu.L., Garmanchuk L.V., Pekhnyo V.I., Skachkova O.V., Vovk M.V. // 
Ukr. Biochem. J. - 2015. - Vol.87. - No. 1. - P.64-74.

15. Synthesis and $\mathrm{X}$-ray crystal structure of the dirhenium complex $\mathrm{Re}_{2}\left(i-\mathrm{C}_{3} \mathrm{H}_{7} \mathrm{COO}\right)_{4} \mathrm{Cl}_{2}$ and its interactions with the DNA purine nucleobases / Shtemenko A.V., Chifotides H.T., Yegorova D.E., Shtemenko N.I., Dunbar K.R. // J. Inorg. Biochem. - 2015. Vol.153. - P.114-120.

Recevied 21.03.2020

\section{СПЕКТРАЛЬНІ ХАРАКТЕРИСТИКИ ТА ЦИТОСТАТИЧНИЙ ВПЛИВ КАРБОТІОАМІДНИХ $\pi$-КОМПЛЕКСІВ Рd(II) I Pt(II) НА КЛІТИНИ МЕРИСТЕМ ALLIUM CEPA L}

П.В. Боровик, С.І. Орисик, Г.Г. Репіч, А.Ф. Ліханов, А.М. Міщенко, Ю.Л. Зборовський, В.В. Орисик, Л.Г. Пальчиковська, В.І. Пехньо, М.В. Вовк

В роботі надано оригінальні результати спектральних характеристик та вперше досліджено механізм иитостати чної та антипрліферативної дї синтезованих аналогів цисплатину на основі $\pi$-комплексів $\mathrm{Pd}(\mathrm{II})$ i $\mathrm{Pt}(\mathrm{II})$ з $\mathrm{N}$-алілморфолін-4карботіоамідом та 1-аліл-3-трет-бутилтіосечовиною на клітини меристем Allium сера $L$. Показано, що електронні спектри поглинання та спектри дифузного відбиття комплексів складаються зі смуг поглинання, які відповідають переходам з перенесенням заряду з ліганду на метал, $d d$-електронним переходам та внутрішньолігандним $\pi \rightarrow \pi^{*}, n \rightarrow \pi^{*}$ електронним переходам з вкладами кратних зв 'язків алільного фрагменту та карботіоамідного угрупування. При цьому смуги поглинання в ультрафіолетовій ділянці спектрів комплексів зазнають гіпсохромного зсуву за відношенням до спектрів самих лігандів, що пов'язано з наявністю координаційного зв язку. Побудовані криві титрування мають слабко виражені перегини при співвідношенні компонентів $M: L=1: 1,1: 2$ mа 1:3, шо свідчить про можливу координацію лігандів в розчині як хетатним, так і нехелатним способом тільки через атоми сірки карботіоамідноі групи. В роботі проведено також і теоретичні квантово-хімічні розрахунки ІЧ-спектрів, що знаходяться в хорошій відповідності з експериментальними даними інфрачервоної спектроскопії. Встановлено, що досліджувані комплекси виявляють специфічну цитостатичну дію на клітини меристем Alliuт сера з високою проліферативною активністю. Внаслідок утворення чисельних зшивок металовмісних препаратів з молекулами ДНК, а також ядерними білками унеможсливлюється нормальна компактизація хроматину. Це призводить до порушення клітинного циклу, зменшення мітотичного індексу $і$ аномалій поділу клітин, що у подальшому зазвичай завершуються апоптозом. л-комплекси паладію викликають диспергування хроматину, що призводить до значних порушень у процесах каріокінезу, внаслідок яких хромосоми втрачають типову структуру, підда ються фрагментації, частіше з втратою теломерних ділянок.

Ключові слова: $\pi$-комплекси, карботіоаміди, коливальна спектроскопія, протипухлинна активність, генотоксичність.

\section{SPECTRAL CHARACTERISTICS AND CYTOSTATIC EFFECT OF Pd(II) AND Pt(II) CARBOTHIOAMIDE $\pi$-COMPLEXES ON ALLIUM CEPA L MERISTEM CELLS}

P.V. Borovyk ${ }^{a}$, S.I. Orysyk ${ }^{a,}{ }^{*}$, H.H. Repich ${ }^{a}$, A.F. Likhanov ${ }^{b}$, A.M. Mishchenko a, , Yu.L. Zborovskii ${ }^{c}$, V.V. Orysyk ${ }^{c}$, L.G. Palchikovska ${ }^{d}$, V.I. Pekhnyo ${ }^{a}$, M.V. Vovk ${ }^{c}$

${ }^{a}$ V.I. Vernadsky Institute of General and Inorganic Chemistry of the National Academy of Sciences of Ukraine, Kyiv, Ukraine

b Institute for Evolutionary Ecology of the National Academy of Sciences of Ukraine, Kyiv, Ukraine

c Institute of Organic Chemistry of the National Academy of Sciences of Ukraine, Kyiv, Ukraine

${ }^{d}$ Institute of Molecular Biology and Genetics of the National Academy of Sciences of Ukraine, Kyiv, Ukraine

e Enamine Ltd., Kyiv, Ukraine

*e-mail: s.oryslend@gmail.com

The spectral characteristics of the synthesized cisplatin analogs based on $\pi$-complexes of Pd(II) and Pt(II) with $N$-allylmorpholine4-carbothioamide and 1-allyl-3-tret-butylthiourea and the mechanism of their cytostatic and antiproliferative action on meristem cells of Allium cepa L. are reported in this work for the first time. It is shown that the electronic absorption and diffuse reflection spectra of complexes show absorption bands corresponding to the transitions with charge transfer from a ligand to metal, dd-electron transitions and intraligand $\pi \rightarrow \pi^{*}$ and $n \rightarrow \pi^{*}$ electronic transitions with the contributions of multiple bonds of allyl moiety and carbothioamide group. In this case, the absorption bands in the ultraviolet region of the spectra of the complexes undergo a hypochromic shift with respect to the spectra of the ligands themselves, which is due to the presence of a coordination link. Analysis of the titration curves shows the possible coordination of the ligands in solution in both chelate and non-chelate ways only through the atoms of sulfur of the carbothioamide group with molar ratios $M: L=1: 1,1: 2$ and 1:3. Theoretical quantum-chemical calculations of the IR spectra are carried out; their results are in good agreement with the experimental data of infrared spectroscopy. It is established that cisplatin analogues exhibit a specific cytostatic effect on Allium cepa meristem cells with high antiproliferative activity. Due to the formation of numerous cross-links of metal-containing preparations with DNA molecules and with nuclear proteins, chromatin is not compacting as normal. This results in a disrupted cell cycle, a decreased mitotic index and anomalous cell division, which are usually followed by apoptosis. Palladium-based $\pi$-complexes cause chromatin dispersion, which leads to significant abnormalities in the processes of karyokinesis, which cause the chromosomes to lose their typical structure and undergo fragmentation, mostly with loss of telomeric sites.

Keywords: $\pi$-complexes; carbothioamides; vibrational spectroscopy; anticancer activity; genotoxicity.

\section{REFERENCES}

1. Repich H.H., Orysyk V.V., Palchykovska L.G., Orysyk S.I., Zborovskii Yu.L., Vasylchenko O.V., Storozhuk O.V., Biluk A.A., Nikulina V.V., Garmanchuk L.V., Pekhnyo V.I., Vovk M.V. Synthesis, spectral characterization of novel Pd(II), Pt(II) $\pi$-coordination compounds based on $\mathrm{N}$-allylthioureas. Cytotoxic properties and DNA binding ability. Journal of Inorganic Biochemistry, 2017, vol. 168, pp. 98-106.

2. Orysyk S.I., Borovyk P.V., Repich H.H., Severynovska O.V., Zborovskii Yu.L., Mishchenko A.M., Orysyk V.V., Pekhnyo V.I., Vovk M.V. Synthesis, spectral characterization and DFT calculations of novel $\mathrm{Ag}(\mathrm{I}) \pi$-coordination polymeric complexes based on N-allylmorpholine-4-carbothioamide. Journal of Molecular Structure, 2020, vol. 1208, article no. 127866. 
3. Biliuk A., Garmanchuk L., Skachkova O., Repich H., Orysyk S. Antineoplastic, anti-metastatic and metabolic effects of newly synthesized platinum complexes. Bulletin of Taras Shevchenko National University of Kyiv - Problems of Physiological Functions Regulation, 2017, vol. 23, no. 2, pp. 69-75.

4. Bilyuk A.A., Storozhuk O.V., Kolotiy O.V., Repich H.H., Orysyk S.I., Garmanchuk L.V. Pt (II) and Pd (II) complexes influence on spheroids growth of breast cancer cells. Biotechnologia Acta, 2017, vol. 10, no. 1, pp. 61-67.

5. Kumar V., Chimni S.S. Recent developments on thiourea based anticancer chemotherapeutics. Anti-Cancer Agents in Medicinal Chemistry, 2015, vol. 15, no. 2, pp. 163-175.

6. Vojtek M., Marques M.P.M., Ferreira I.M.P.L.V.O., Mota-Filipe H., Diniz C. Anticancer activity of palladium-based complexes against triple-negative breast cancer. Drug Discovery Today, 2019, vol. 24, pp. 1044-1058.

7. Kapdi A.R., Fairlamb I.J.S. Anti-cancer palladium complexes: a focus on PdX2L2, palladacycles and related complexes. Chemical Society Reviews, 2014, vol. 43, pp. 47514777.

8. Marques-Gallego P., den Dulk H., Brouwer J., Kooijman H., Spek A.L., Roubeau O., Teat S.J., Reedijk J. Synthesis, crystal structure, studies in solution and cytotoxicity of two new fluorescent platinum(II) compounds containing anthracene derivatives as a carrier ligand. Inorganic Chemistry, 2008, vol. 47, pp. 11171-11179.
9. Kesharwani M.K., Brauer B., Martin J.M.L. Frequency and zero-point vibrational energy scale factors for double-hybrid density functionals (and other selected methods): can anharmonic force fields be avoided? Journal of Physical Chemistry A, 2015, vol. 119, pp. 1701-1714.

10. Barberio A., Voltolini J.C., Mello M.L. Standardization of bulb and root sample sizes for the Allium cepa test. Ecotoxicology, 2011, vol. 20, pp. 927-935.

11. Pearse A.G., Histochemistry: theoretical and applied. Churchill, London, 1968.

12. Kazitsyna L.A., Kupletskaya N.B., Primenenie UF, IK i YaMR spektroskopii $v$ organicheskoi khimii [The application of UV-vis, IR and NMR spectroscopy in organic chemistry]. Vysshaya Shkola Publishers, 1971. 264 p. (in Russian).

13. Buslaeva T.M., Simanova S.A. State of platinum metals in hydrochloride acidic and chlorides solutions. Palladium, platinum, rhodium and iridium. Russian Journal of Coordination Chemistry, 1999, vol. 25, pp. 165-176.

14. Orysyk S.I., Repich G.G., Andrushchenko O.O., Nikulina V.V., Orysyk V.V., Zborovskii Y.L., Garmanchuk L.V., Pekhnyo V.I., Skachkova O.V., Vovk M.V. Effect of Pd(II) and $\mathrm{Ni}(\mathrm{II})$ coordination compounds with 4-amino-3-mercapto-5methyl-1,2,4-triazole on the mitochondrial dehydrogenases activity. Ukrainian Biochemical Journal, 2015, vol. 87, no. 1, pp. 64-74.

15. Shtemenko A.V., Chifotides H.T., Yegorova D.E., Shtemenko N.I., Dunbar K.R. Synthesis and X-ray crystal structure of the dirhenium complex $\mathrm{Re}_{2}\left(\mathrm{i}-\mathrm{C}_{3} \mathrm{H}_{7} \mathrm{COO}\right)_{4} \mathrm{Cl}_{2}$ and its interactions with the DNA purine nucleobases. Journal of Inorganic Biochemistry, 2015, vol. 153, pp. 114-120. 